\title{
Middle East Respiratory Syndrome and Blood Donation: Topic for Further Study and Discussion
}

\author{
Viroj Wiwanitkit
}

Received: 11 June 2014/ Accepted: 20 August 2014/Published online: 6 September 2014

(C) Indian Society of Haematology \& Transfusion Medicine 2014

Sir, an interesting new emerging infectious disease, which is the present concern in global public health, is the novel Middle East respiratory syndrome (MERS). This disease was first seen in Saudi Arabia and it spreads into many countries around the world [1-3]. The consideration is on the possible worldwide outbreak of this disease. This new disease is an acute respiratory illness with high fatality. This new disease is of great concern. Until present (record at 31 July 2014), there are 853 reported cases with 331 deaths from 21 countries around the world. At present, MERS is under surveillance from center disease of control. The disease investigation is suggested for any cases with unexplained febrile illness with respiratory symptoms [1-3]. To diagnose, the specific molecular biology test is required. In addition, until present, there is still no specific antiviral drug [1-3]. To prevent of infection is widely mentioned. Most preventive method focuses on the quarantine of suspected cases, especially those with history of travel to epidemic areas and the use of respiratory infection control measure [1-3]. However, the exact mode of transmission of MERS is still a myth. In transfusion medicine, the important concern is the possibility of disease transmission via blood

\footnotetext{
V. Wiwanitkit

Hainan Medical University, Haikou, China

V. Wiwanitkit

Faculty of Medicine, University of Nis, Niš, Serbia

V. Wiwanitkit

Joseph Ayobabalola University, Ikeji-Arakeji, Nigeria

V. Wiwanitkit

Surin Rajabhat University, Surin, Thailand

V. Wiwanitkit $(\square)$

Wiwanitkit House, Bangkhae, Bangkok 10160, Thailand

e-mail:wviroj@yahoo.com
}

transfusion. The present correspondence is aiming at alerting the national and international scientific community on this new emerging disease. Since virus causing MERS is a coronavirus resembling to that causes severe respiratory distress syndrome (SARS), the concern on possibility of transmission via blood transfusion should be specially focused. Focusing on SARS, the risk of blood transfusion transmission is confirmed [4] and the inactivation of virus in contaminated blood is the present research topic [5]. However, until present, there is still no case report of MERS transmitted by blood transfusion. There is an interesting report from Saudi Arabia [6]. During emerging of disease in Saudi Arabia, Aburizaiza et al. [6] studied donated blood samples by immunofluorescence assay and reported no positive finding. This might implies the low or no risk of MERS transmission via blood transfusion. Nevertheless, there are many considerations. First, using immunological method for determination of MERS virus might be possible but it is not a gold standard. Immunological method is inferior to standard PCR test [7]. Nevertheless, in confirmed MERS cases, the chance to detect the virus in blood sample is also very low [7]. Therefore, this might conclude that there is a low chance for transmission of virus by donated blood. On the other hand, the non contaminated blood cannot be guaranteed that it is from non infected cases.

Conflict of Interest The author is appointed as an editorial board member of the IJHBT journal.

\section{References}

1. Hajjar SA, Memish ZA, McIntosh K (2013) Middle East Respiratory Syndrome Coronavirus (MERS-CoV): a perpetual challenge. Ann Saudi Med 33:427-436 
2. Al-Tawfiq JA (2013) Middle East respiratory syndrome-coronavirus infection: an overview. J Infect Pub Health 6:319-322

3. Wiwanitkit V (2014) Novel Middle East respiratory syndrome coronavirus. J Formos Med Assoc 113:65

4. Shang G, Biggerstaff BJ, Yang B, Shao C, Farrugia A (2007) Theoretically estimated risk of severe acute respiratory syndrome transmission through blood transfusion during an epidemic in Shenzhen, Guangdong, China in 2003. Transfus Apher Sci 37:233-240

5. Darnell ME, Taylor DR (2006) Evaluation of inactivation methods for severe acute respiratory syndrome coronavirus in noncellular bloodproducts. Transfusion 46:1770-1777
6. Aburizaiza AS, Mattes FM, Azhar EI et al (2014) Investigation of anti-middle East respiratory syndrome antibodies in blood donors and slaughterhouse workers in Jeddah and Makkah, Saudi Arabia, fall 2012. J Infect Dis 209:243-246

7. Al-Abdallat MM, Payne DC, Alqasrawi S et al. (2014) Hospitalassociated outbreak of Middle East respiratory syndrome coronavirus: a serologic, epidemiologic, and clinical description. Clin Infect Dis 2014 May 14 (Epub ahead of print) 